\title{
Drought and grazing III: Root dynamics and germinable seed bank
}

\author{
A. L. HILD, M. G. KARL, M. R. HAFERKAMP, AND R. K. HEITSCHMIDT
}

Authors are assistant professor, Department of Renewable Resources, University of Wyoming, Laramie, Wyo. 82071; rangeland management specialist, USDI-Bureau of Land Management, Interior Columbia Basin Ecosystem Management Project, Boise, Ida, 33702; rangeland scientist, and supervisory rangeland scientist, USDA Agricultural Research Service, Fort Keogh Livestock and Range Research Laboratory, Miles City, Mont. 59301. At the time of the research, M. G. Karl and A. L. Hild were postdoctoral rangeland scientists at Fort Keogh.

\begin{abstract}
Drought and herbivory frequently influence North American rangelands. While these influences may temporarily reduce vegetative cover, their mutual influence on the available seedbanks which might occupy new safe sites is unclear. We examine effects of drought and grazing upon pre- and post-drought plant root distribution and germinable seed bank to determine 1) if the response of root distributions to drought depends upon grazing use and 2) if the presence of germinable seeds is altered significantly by drought and grazing. Using twelve, 5 X 10 m nonweighing lysimeters with an automated rainout shelter, we documented root intercepts in situ using a minirhizotron from 19931996. Seed bank samples were incubated in a greenhouse to determine seedling emergence. Roots were fewer in shallow soil layers in grazed plots than ungrazed plots by the end of the study, irrespective of drought. Roots in deeper (Bw horizon) soil layers were fewer during drought, but were not influenced by grazing. Seed bank composition results suggest that perennial grasses were a small portion of the seed bank. Cool-season annual grass seeds accumulated after drought. Without drought, forb seed banks increased with grazing. Thus while shallow roots may decrease during drought, in the year following drought grazing may decrease aboveground net primary production, and allow large accumulations of cool-season annual grass seed in a northern mixed grass prairie.
\end{abstract}

Key Words: minirhizotron, northern mixed grass prairie, seed banks

Drought and herbivory commonly affect the structure and function of grasslands. Historically, studies evaluating the effects of drought and grazing have focused on in situ post-drought recovery patterns, such as those after droughts in the 1930s and 1980s (e.g. Albertson and Weaver 1944, 1946). Controlled in situ drought experiments are uncommon although notable exceptions

This research was conducted under a cooperative agreement between USDAARS and the Montana Agric. Exper. Sta. Mention of a proprietary product does not constitute a guarantee or warranty of the product by USDA, Montana Agric. Exp. Sta., or the authors and does not imply its approval to the exclusion of other products that may also be suitable. USDA- Agricultural Research Service, Northern Great Plains Area, is an equal opportunity/affirmative action employer and all agency services are available without discrimination.

Authors thank Cheryl Murphy, Mish Speelmon-Leidholt, and numerous staff at Ft. Keogh LARRL for their assistance with this research.

Manuscript accepted 3 July. 2000.

\section{Resumen}

La sequía y herbívora frecuentemente influyen en los pastizales de Norteamérica. Mientras esta influencia puede reducir temporalmente la cobertura vegetativa, su influencia muta en los bancos de semillas disponibles, los cuales pudieran ocupar nuevos sitios seguros, aun no es clara. Examinamos los efectos de la sequía y el apacentamiento en la distribución de raíces y el banco de semillas germinables antes y después de la sequía para determinar: 1) si la respuesta de la distribución de las raíces a la sequía depende del grado de apacentamiento y 2) si la presencia de semillas germinables es alterada significativamente por la sequía y el apacentamiento. De 1993 a 1996 documentamos la intercepción de raíces mediante un mini-rizoton, la determinación se realizó en 12 lisímetros no pesables de 5 x 12 m equipados con un protector automático contra la lluvia. Las muestras del banco de semilla se incubaron en un invernadero para determinar la emergencia de las plántulas. Al termino del estudio, independientemente de la sequía, el número de raíces en las capas superficiales de suelo fue menor en las parcelas con apacentamiento que las en las parcelas sin apacentamiento. El número de raíces en las zonas profundas del suelo (horizonte Bw) fue menor durante la sequía, pero no fueron influenciadas por el apacentamiento. Los resultados de la composición del banco de semilla sugieren que los zacates perennes fueron una pequeña proporción del banco de semilla. Las semillas de los zacates anuales de estación fría se acumularon después de la sequía. Sin sequía los bancos de semillas de hierbas aumentaron con el apacentamiento. Así, mientra que las raíces superficiales pueden disminuir durante la sequía, en el año siguiente a la sequía el apacentamiento puede disminuir la producción primaria neta aérea y permitir grandes acumulaciones de semilla de zacates anuales de estación fría en las praderas de zacates mixtos del norte.

have occurred (e.g. Ansley et al. 1992). We hypothesized that combined effects of drought and grazing may reduce root presence and vegetative cover while simultaneously favoring portions of the seed bank. Such combined impacts could precede a transition to increased presence of particular seed bank dominants.

Removal of above-ground biomass from perennial graminoids generally decreases root growth and root biomass (Robertson 1933, Carter and Law 1948, Crider 1955, Schuster 1964, Bartos and Jameson 1974) although exceptions have occurred (Bartos and Sims 1974). While most root response studies have used either potted plant or destructive excavation techniques (Cook 
and Stubbendieck 1986), optic in situ techniques (Waddington 1971, Richards 1984) were refined and have provided researchers with new opportunities to evaluate root response to an array of imposed treatments.

Seed banks provide a glimpse of both past conditions and vegetation potentials, and drought and herbivory are but 2 elements of an "environmental sieve" (Harper 1977) that affect seed bank composition. Although seed bank and overstory vegetation composition are seldom identical (Rice 1989, Major and Pyott 1966), seed banks do provide insight into shifts in plant species composition during recovery from stressful events.

Objectives of this study were to examine concurrent impacts of drought and grazing on root and seed bank dynamics in a Northern mixed grass rangeland to assess potential creation of open sites (reduced root presence) concurrent with changes in the seed bank. This research compliments previous work which addressed primary production (Heitschmidt et al. 1999), and tiller growth dynamics (Enboe 1996). In situ minirhizotron technology was used to examine impacts of drought and grazing on root dynamics. Seedling emergence in a controlled environment was used as an estimate of the propagules available for postdrought recovery (Simpson et al. 1989).

\section{Materials and Methods}

Research was conducted at the Fort Keogh Livestock and Range Research Laboratory near Miles City, Mont. (46 ${ }^{\circ}$, $\left.22^{\prime} \mathrm{N} 105^{\circ}, 5^{\prime} \mathrm{W}\right)$ from 1993 through 1996. Regional topography ranges from rolling hills to broken badlands with small intersecting streams which flow into rivers in broad nearly level valleys. Potential natural vegetation is a grama-needle grasswheatgrass (Bouteloua-Stipa-Agropyron) mixed grass community (Kuchler 1964). Precipitation averages $34 \mathrm{~cm}$ with $60 \%$ received between mid-April and midSeptember. Average daily temperatures range from $-10^{\circ} \mathrm{C}$ in January to $24^{\circ} \mathrm{C}$ in July with maximum temperatures occasionally exceeding $37^{\circ} \mathrm{C}$ in summer and minimums below $-40^{\circ} \mathrm{C}$ in winter. The frost-free growing period is about 150 days. Soils of the study area are Kobase silty clay loam, fine, montmorillonitic, frigid, Aridic Ustochrepts (USDA 1996). The typic profile description for the Kobase silty clay loam includes an A horizon from 0-22 cm, a Bw horizon from $20-46 \mathrm{~cm}$, a Bk horizon 46-66 cm, and
$\mathrm{C} 1$ and C2 horizons to 90 and $150 \mathrm{~cm}$ depths respectively.

Twelve, 5 X 10 m non-weighing lysimeters were constructed in 1992 on a gently sloping (4\%) clayey range site (Heitschmidt et al. 1999). An automatic rainout shelter was constructed over 6 of the 12 lysimeters to impose drought (Larsen et al. 1993). Drought was imposed on 6 lysimeters from late May to midOctober 1994. Within each water treatment (drought or non-drought), 1 of 3 grazing treatments was applied to 2 replicate lysimeter plots: 1) graze the year of and the year after simulated drought, hereafter referred to as the G 94\&95 treatment; 2) graze during the year of drought and rest the year after, hereafter referred to as the $G$ 94 treatment; and 3) rest the year of and the year after drought, hereafter referred to as the ungrazed treatment. Grazed plots were grazed intensively by 6 ewes and their twin lambs for a few hours in early June and early July 1994 and 1995. Defoliation in grazed plots reduced standing crop an average of $980 \mathrm{~kg} \mathrm{ha}^{-1}$ relative to ungrazed plots (Heitschmidt et al. 1999).

Precipitation, soil water patterns, and aboveground herbaceous production have been reported previously (Heitschmidt et al. 1999). In general, 1993 precipitation immediately before initiation of treatments was $38 \%$ above long-term means, while precipitation in 1994, the first year of the drought and grazing treatments, was $24 \%$ below the 115 year average (NOAA 1996). Precipitation in 1995 and 1996 was near normal ( 95 and $86 \%$ of the 115 average), although rainfall in May 1996 was $200 \%$ above the month's norm (Fig. 1).

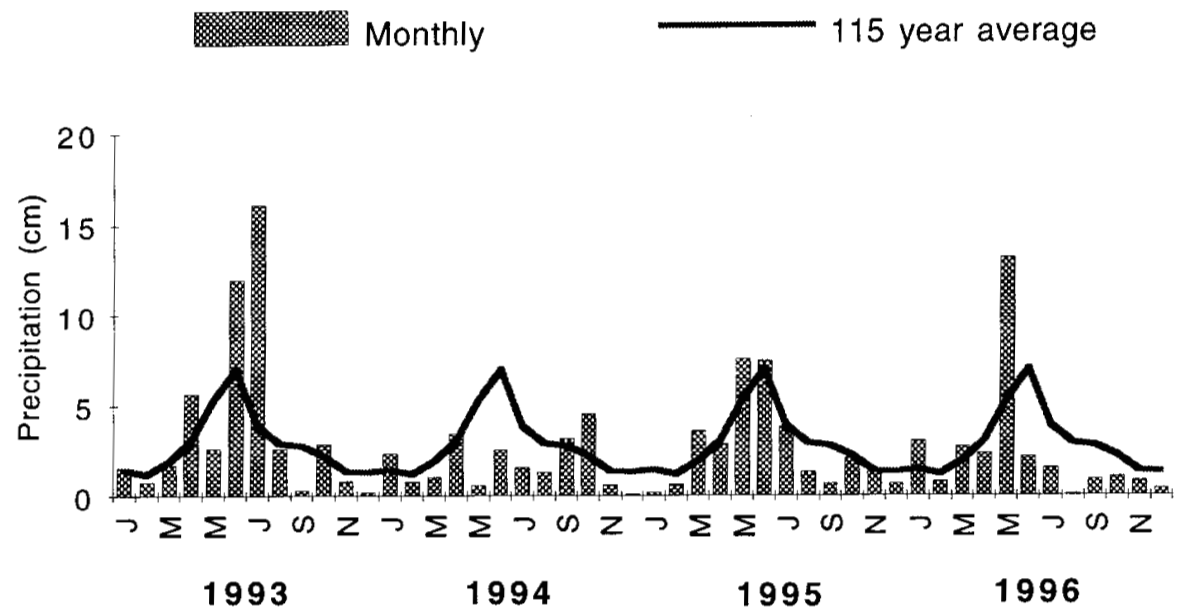

Monthly

\section{Root counts}

Root intercepts were counted in situ using a minirhizotron (Richards 1984, Taylor 1987). Minirhizotron observation tubes $(38 \mathrm{~mm}$ inside diameter X $122 \mathrm{~cm}$ long) were installed at a $30^{\circ}$ angle from vertical in each plot at initiation of the study in 1992. These small diameter tubes offer the least disturbance to roots, which is especially important for perennial species (Richards 1984). Roots were counted if they intersected a line circumscribed on the tube at each depth (Taylor 1987, Upchurch 1987). Root counts were separated into 3 functional categories by color: white, new roots; tan, suberized roots; and black, dead or dying roots. Roots were observed in 2 minirhizotron tubes per lysimeter at 10 depths per minirhizotron (marks were inscribed 5, 15, $25,35,45,55,65,75,85$, and $95 \mathrm{~cm}$ along the tube length). Beginning at the soil surface, the first mark inscribed upon the tube was located at $5 \mathrm{~cm}$ below the soil surface, and since the tube was placed at $30^{\circ}$ from vertical, the $95 \mathrm{~cm}$ mark corresponds to a $77 \mathrm{~cm}$ soil depth. Root intersections were recorded on 42 sample dates beginning in April 1993 and ending in November 1996.

\section{Seed bank sampling procedures}

Within each lysimeter, samples of surface litter and underlying soils were extracted. Litter samples were extracted using a hand vacuum, from 6 randomly located $100-\mathrm{cm}^{2}$ circular subplots within each lysimeter. Soil core samples were removed from each of the 6 subplots with a $100-\mathrm{cm}^{2}$ core sampler to a depth of $3 \mathrm{~cm}$. Litter and soil core samples were bagged separately, and transported to the laboratory for incubation. Sample dates were the

Fig. 1. Monthly precipitation (cm) from Jan. 1993- Dec. 1996, and long-term (115 year) average at Miles City, Mont. (NOAA 1996). 
Table 1. Emerged seedling species within 4 functional groups. Nomenclature follows Dorn 1984.

\begin{tabular}{|c|c|c|}
\hline Functional group & Species & Common name \\
\hline $\begin{array}{c}\text { Annual grasses } \\
\text { (cool-season) }\end{array}$ & $\begin{array}{l}\text { Bromus tectorum L. } \\
\text { Bromus japonicus Thunb. es Murr. } \\
\text { Hordeum pusillum Nutt. } \\
\text { Vulpia octoflora Walt. Rydb. }\end{array}$ & $\begin{array}{l}\text { downy brome } \\
\text { Japanese brome } \\
\text { foxtail barley } \\
\text { sixweeks fescue }\end{array}$ \\
\hline $\begin{array}{l}\text { Perennial grasses } \\
\text { (cool-season) }\end{array}$ & $\begin{array}{l}\text { Pascopyron smithii Rydb. (Love) } \\
\text { Poa secunda Vasey } \\
\text { Stipa comata Trin. \& Rupr. }\end{array}$ & $\begin{array}{l}\text { western wheatgrass } \\
\text { Sandberg bluegrass } \\
\text { needle-and-thread }\end{array}$ \\
\hline (warm-season) & $\begin{array}{l}\text { Bouteloua gracilis (H. B. K.) Lag. ex Griffiths } \\
\text { Buchloe dactyloides (Nutt.) Engelm. } \\
\text { Schedonnardus paniculatus (Nutt.) Trel. } \\
\text { Sporobolus crypandrus (Torr.) }\end{array}$ & $\begin{array}{l}\text { blue grama } \\
\text { buffalograss } \\
\text { Texas tumblegrass } \\
\text { sand dropseed }\end{array}$ \\
\hline Forbs & $\begin{array}{l}\text { Androsace occidentalis Pursh. } \\
\text { Camelina microcarpa Andrz. ex D. C. } \\
\text { Conyza canadensis (L.) Cronq. } \\
\text { Convoluvus arvensis L. } \\
\text { Descurainia pinnata (Walt.) Britt. } \\
\text { Descurainia sophia (L.) Webb ex Prant } \\
\text { Draba reptans var. mirantha (Lam.) Fern. } \\
\text { Euphorbia glyptosperma Engelm. } \\
\text { Euphorbia spathulata Lam. } \\
\text { Filago arvensis } \text { (L.) L. } \\
\text { Hedeoma hispidum Pursh. } \\
\text { Kocia scoparia } \text { (L.) Schrad. } \\
\text { Lactuca serriola L. } \\
\text { Lepidium densiflorum Schrad. } \\
\text { Linum rigidum Pursh. } \\
\text { Melilotus officinalis (L.) Pallas } \\
\text { Plantago patagonica Jacq. } \\
\text { Salsoa iberica Sennen \& Pau } \\
\text { Sisybrium altissimum L. } \\
\text { Sisybrium irio L. } \\
\text { Sphaeralcea coccinea (Nutt.) Rydb. } \\
\text { Taraxacum officinale Weber } \\
\text { Triodanis leptocarpa (Nutt.) Nieuwl. } \\
\text { Tragopogon dubius Scop. }\end{array}$ & $\begin{array}{l}\text { fairy candleabra } \\
\text { little falseflax } \\
\text { horseweed } \\
\text { bindweed } \\
\text { pinnate tansymustard } \\
\text { flixweed tansymustard } \\
\text { Carolina whitlowgrass } \\
\text { ridgeseed spurge } \\
\text { spatulate-leaved spurge } \\
\text { fluffweed } \\
\text { rough falsepennyroyal } \\
\text { summer cypress } \\
\text { prickly lettuce } \\
\text { prairie pepperweed } \\
\text { stiffstem flax } \\
\text { yellow sweetclover } \\
\text { wooly Indian wheat } \\
\text { Russian thistle } \\
\text { tumble mustard } \\
\text { ironweed mustard } \\
\text { scarlet globemallow } \\
\text { dandelion } \\
\text { Venus' looking glass } \\
\text { salsify }\end{array}$ \\
\hline
\end{tabular}

weeks of 4 October 1993; 23 September 1994; 27 September 1995; and 23 September 1996.

\section{Greenhouse seedling emergence}

At the lab, soil and litter samples were separately placed into prepared pots (18 $\mathrm{cm}$ diameter X $16.5 \mathrm{~cm}$ deep) within 2 days of sample collection. Within each sterilized pot, we placed a round filter paper in the bottom and then filled pots with sterilized sand to within $2.5 \mathrm{~cm}$ of the top edge. Another filter paper was placed on the sand surface to prevent seeds from becoming buried too deeply. Next, litter samples mixed with $200 \mathrm{~cm}^{3}$ of additional sterilized sand were placed on top of the filter paper. Soil core samples were hand crushed and placed into different pots in the same manner as litter samples. Exposed seeds were buried, and pots were placed in a greenhouse maintained at temperatures ranging from $21-13^{\circ} \mathrm{C}$. Pots were watered daily in the first week and periodically thereafter to keep surface soil moist. Lighting was supplied to mimic 12hour days.

Samples were incubated for 12 weeks each year, and emerged seedlings were counted by species at 2 week intervals and then removed by hand pulling or clipping. Unidentified seedlings were not removed until they could be identified. Individual pot counts (subsamples were 6 litter and 6 soil core pots per lysimeter) were totaled within year, and seedlings were divided into 4 functional plant type groups for analyses: forbs, warm-season perennial grasses, cool-season perennial grasses, and cool-season annual grasses. Species encountered (nomenclature follows Dorn 1984) within each functional group are listed in Table 1. Our results reflect germinable seed counts based upon successful emergence in a greenhouse setting. Viable dormant seed was not estimated.

\section{Root count data summary and analysis}

Counts of black roots were omitted from analyses because they were observed only in 4 instances $(<0.1 \%$ of observations) in 1993 before initiation of treatments. Likewise, $\tan$ roots were observed $<1 \%$ of the time, and so they were combined with white root counts to provide an estimate of total live root intersections. Root counts were summed within each minirhizotron tube within 4 soil horizons and averaged by number of soil depths contained within each of the 4 soil horizons (A, Bw, Bk, and $\mathrm{C}$ ). Thus, although roots were observed at each $10-\mathrm{cm}$ mark, root counts reported as number of roots within a soil horizon provide a more meaningful representation of soil profile conditions. The A horizon included 5 and $15-\mathrm{cm}$ tube depths; Bw horizon 25-, 35-, and 45-cm; and Bk horizon $55-$ and $65-\mathrm{cm}$. Three tube depths (75-, 85-, and 95-cm) were combined into the $\mathrm{C}$ horizon, where very few roots were observed.

Root count data were analyzed within each soil horizon ( $\mathrm{A}, \mathrm{Bw}, \mathrm{Bk}$, and $\mathrm{C}$ ) using repeated measures analysis of variance procedures (Table 2). Each of 3 grazing treatments were replicated twice within drought and non-drought treatments; replicates were plots (i.e. lysimeter). The error term for testing simple effects of drought, grazing and their interaction was plot within drought and grazing treatment.

Table 2. Root count ANOVA model and $P$ values by soil horizon on 42 sampling dates from April 1993 to November 1996, at Fort Koegh LARRL, Miles City, Mont.

\begin{tabular}{lcccc}
\hline \hline Source & df & A horizon & Bw horizon & Bk horizon \\
\hline Drought & 1 & 0.29 & 0.27 & 0.10 \\
Graze & 2 & 0.17 & 0.23 & 0.42 \\
Drought*Graze & 2 & 0.21 & 0.09 & 0.08 \\
Error & 6 & & & $\mathbf{0 . 0 1}$ \\
Date & 41 & $\mathbf{< 0 . 0 1}$ & $\mathbf{0 . 0 1}$ & 0.89 \\
Date*Drought & 41 & 0.18 & $<\mathbf{0 . 0 1}$ & 0.82 \\
Date*Graze & 82 & $<\mathbf{0 . 0 1}$ & 0.49 & 0.16 \\
Date*Drought*Graze & 82 & 0.98 & & \\
Error & 246 & & & \\
Total & 504 & & & \\
\hline
\end{tabular}


Table 3. Seed bank ANOVA model and $P$ values by plant functional group, 1993-1996, at Fort Koegh LARRL, Miles City, Mont.

\begin{tabular}{lrcrrrr}
\hline \hline Source & df & TOTAL $^{1}$ & CSAG & CSPF & WSPG & FORB \\
\hline Drought & 1 & 0.33 & 0.87 & 0.13 & 0.08 & $\mathbf{0 . 0 1}$ \\
Graze & 2 & 0.70 & 0.67 & 0.99 & 0.35 & 0.05 \\
Drought*graze & 2 & 0.23 & 0.33 & 0.53 & 0.93 & $\mathbf{0 . 0 4}$ \\
Error & 6 & & & & & \\
Year & 3 & $\mathbf{0 . 0 1}$ & 0.05 & $<\mathbf{0 . 0 1}$ & $<\mathbf{0 . 0 1}$ & $<\mathbf{0 . 0 1}$ \\
Year*Drought & 3 & $\mathbf{0 . 0 1}$ & $\mathbf{< 0 . 0 1}$ & 0.13 & 0.65 & $\mathbf{0 . 0 4}$ \\
Year*Graze & 6 & 0.28 & 0.18 & 0.48 & 0.17 & 0.67 \\
Year*Drought*Graze & 6 & 0.32 & 0.24 & 0.92 & 0.94 & 0.28 \\
Error & 18 & & & & & \\
Total & 47 & & & & & \\
\hline
\end{tabular}

Columns are: total number of seedlings, cool-season annual grasses (CSAG), cool-season perennial grasses (CSPG), warm-season perennial grasses (WSPG), and forbs.

The 42 sampling dates constituted repeated measures. Full model residuals served as the error term for testing sampling date effect and its interaction with treatment effects. When analysis of variance revealed treatment differences, mean separation was completed using Fishers L.S.D. at a 0.05 alpha level, and error terms specific to the contrast (Carmer and Swanson 1971). Data were tested for conformance to assumptions of normality (Shapiro and Wilk 1965).

\section{Seed bank data summary and analysis}

Seedling data were analyzed within functional group (cool-season annual grasses, cool-season perennial grasses, warm-season perennial grasses, or forbs) using repeated measures analysis of variance procedures (Table 3 ). Seedlings emerging from litter and core samples (pots) within a plot were summed for analysis. In addition to the species listed (Table 1), 1 seedling of the shrub Ceratoides lanata (Pursh.) Howell and succulent Opuntia polycantha Haw. were encountered but excluded from analysis. Each of 3 grazing treatments were replicated twice within drought and nondrought treatments; replicates were plots (i.e., lysimeter). The error term for testing simple effects of drought, grazing, and their interaction was plot within drought and grazing treatment. The 4 years of the study were included as repeated measures. Full model residual error was used to test the simple effect of year and its interactions with treatment effects. When analysis of variance revealed treatment differences, mean separation was completed using L.S.D. at a 0.05 alpha level, using error terms specific to the contrast. All data were tested for conformance to assumptions of normality (Shapiro and Wilk 1965). L.S.D.

\section{Greenhouse seedling emergence}

Two-way interactions between drought and year effects occurred only for seedlings of cool-season annual grasses and total seedlings (Table 3). In general, emerged seedlings from combined soil and litter samples were dominated by forb and cool-season annual grasses, with few perennial grass seeds present (Fig. 4). Total seedling emergence differed between drought treatments in 1994-1996, but not in 1993 (Table 3, and Fig. 4). Seedling totals were greater in nondrought than drought treatments in 1994 and 1996, but were less than in the drought treatment in 1995.

Cool- and warm-season perennial grasses (analyzed separately) were not affected by drought or grazing, but differed among years (Table 3 ). Averaged across drought and grazing treatments, more cool-season perennial grass seedlings emerged $\left(23 \mathrm{~m}^{-2}\right)$ in 1996 than the $2-10$ seedlings $\mathrm{m}^{-2}$ that emerged1993-1995. Warm-season perennial grass seedlings were more numerous in 1994 and 1996 ( 23 and $35 \mathrm{~m}^{-2}$ ) than in 1993 and 1995 (7 and $8 \mathrm{~m}^{-2}$ ).

Cool-season annual grass seedlings were similar among grazing treatments, but differed between drought treatments, depending upon year (drought by year interaction, Table 2, Fig. 4). Emerged seedlings were similar between treatments in 1993 and 1996, the year prior to the imposed drought and 2 years after drought. In 1994, cool-season annual grass seedlings were fewer in drought than non-drought plots (Fig. 4). Conversely, in 1995, the year immediately following drought, cool-season annual grass seedlings were greater in drought plots than non-drought plots.

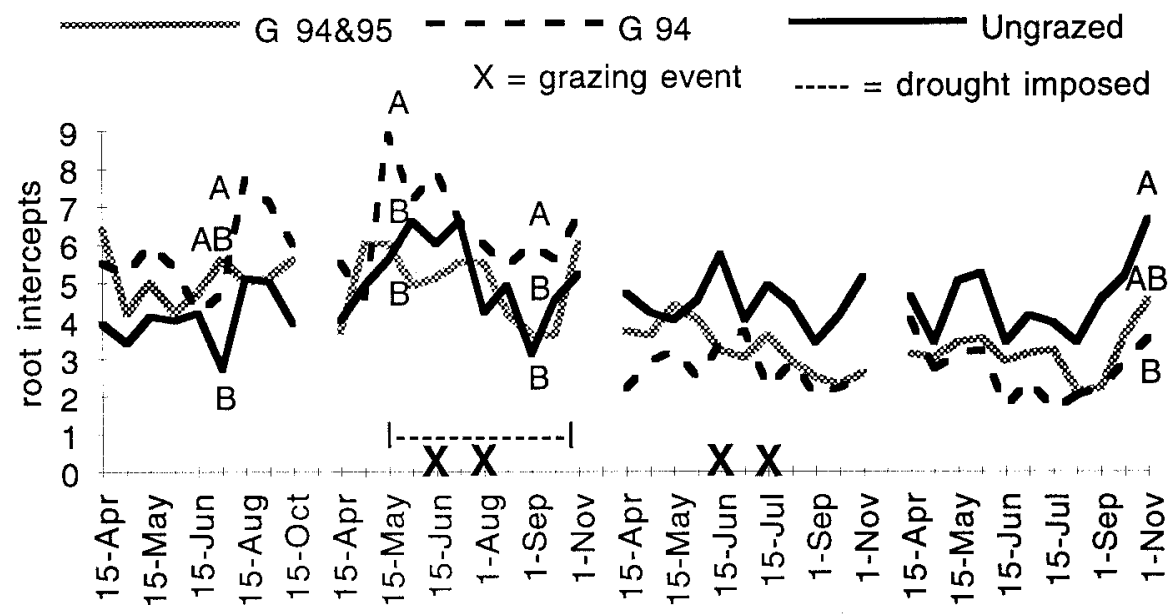

Fig. 2. Root intercepts in the A soil horizon by grazing treatment from April 1993-Nov. 1996. Within a date, grazing treatments with the same upper case letters do not differ $P>0.05$, 


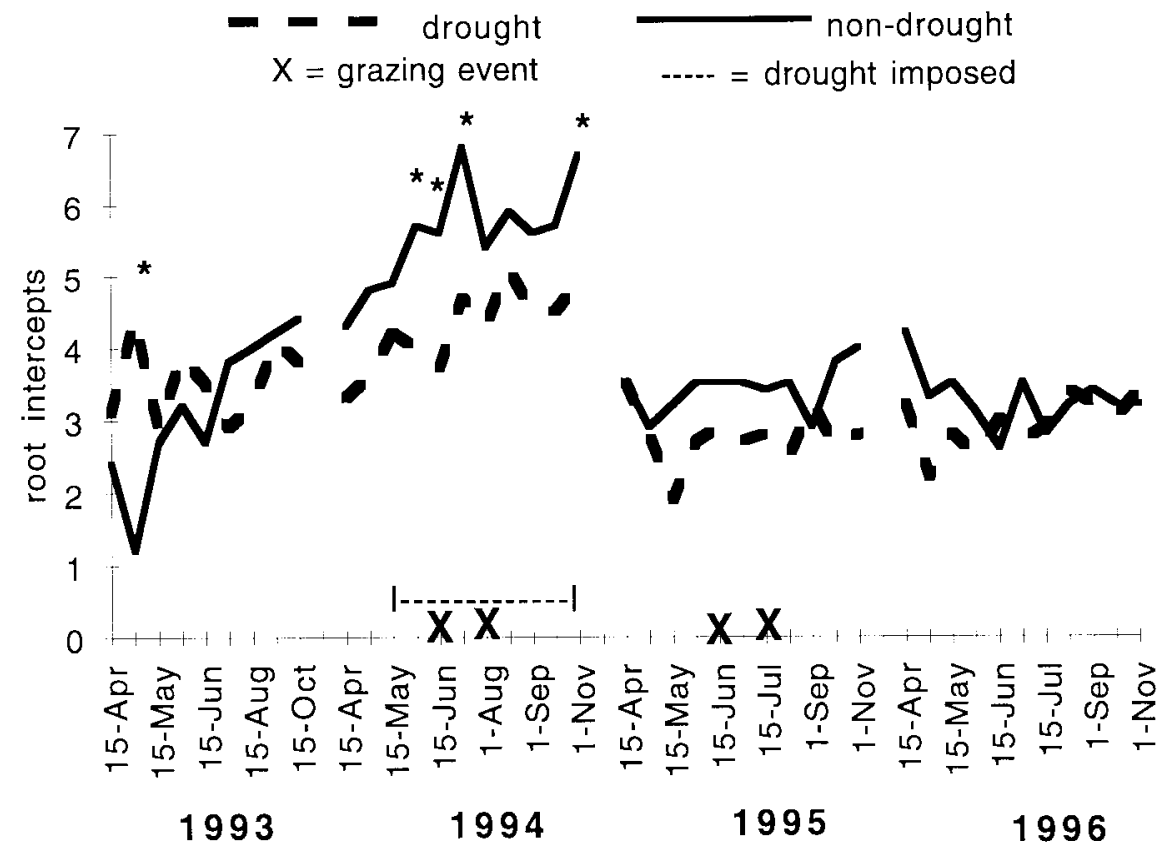

Fig. 3. Root intercepts in the Bw soil horizon by drought treatment, April 1993-Nov. 1996. Within a date, drought treatments with an asterisk differ $P<0.05$, L.S.D.

Forb seedlings were affected by drought, depending upon grazing treatment and year (Table 3). Irrespective of grazing treatments, more forb seedlings were present in 1994 and 1995 than in 1993 , in drought and non-drought treatments (Fig. 4). Forb seedlings in nondrought plots increased from 1993 to 1996 and were more numerous than in drought plots in 1996. Forb seedlings in drought plots were similar from 19941996. Irrespective of year, forb seedlings were similar in ungrazed drought and nondrought plots (131 and $115 \mathrm{~m}^{-2}$ ). In both G94\&95 and G94 treatments, fewer forb seedlings were present in drought (133 and $114 \mathrm{~m}^{-2}$ ) than in non-drought plots (260 and $242 \mathrm{~m}^{-2}$ ).

\section{Discussion}

Early moisture, followed by a relatively dry summer may have limited the impacts of our drought treatment (Heitschmidt et al. 1999). Even so, both root and seedbank differences in drought and non-drought plots were observed. We conclude that; 1) drought tended to limit subsoil (Bw) roots regardless of grazing treatment; 2 ) shallow roots in the A horizon were least in ungrazed plots initially, and were greatest in ungrazed plots at the end of the study, regardless of drought treatment; 3 ) forb seedlings increased in grazing treatments

\section{Root dynamics}

Differences in root counts in the Bw soil horizon suggest that the 2 moisture treatments differed prior to imposing drought treatments. There is no obvious explanation for differences observed in root counts in the Bw horizon in the first week of May 1993. However, 2 factors might help to explain this pre-treatment difference. Spring 'draw down' of root biomass in grasslands has been associated with early wet-season foliage growth (McNaughton et al. 1998); early season draw down of root biomass is followed by increased root biomass at the end of the wet season. Our results also demonstrate root declines with early spring growth and maximum root presence at the end of the growing season. We suggest that Figure 3 demonstrates a lag in the draw down in drought versus non-drought plots in April and May (excepting 1994 when very dry conditions in all plots may have limited the draw down effect). Since, our nondrought plots contained more cool-season grasses than drought plots (Heitschmidt et al. 1999), the draw down effect in drought plots may have been delayed by later growth of warm-season grasses, and thus lagged behind root declines in nondrought plots. The lag in timing of spring root declines in 1993 may explain the significant difference between the 2 treatments in May.

Lack of shallow root (A horizon) response to drought treatment is informative. We suggest that sufficient soil water was present before imposing drought treat- only in the absence of drought; 4) germinable seed bank species composition increased following drought; and - and cool-season perennial gras were a minor portion of the seed bank and did not differ among grazing or drought treatments.

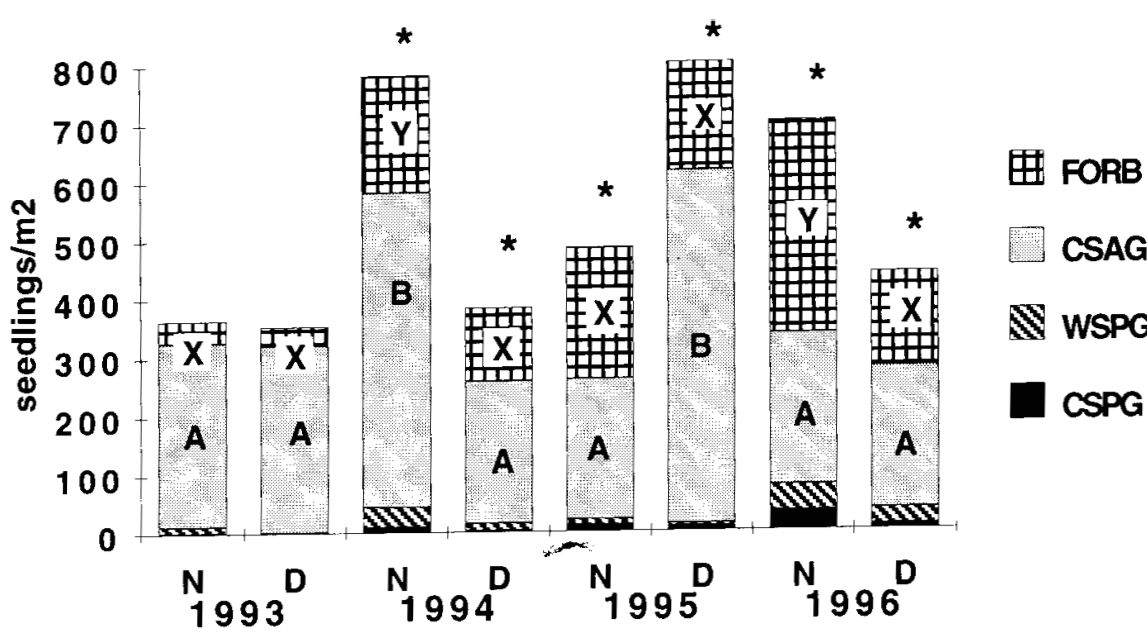

Fig. 4. Emerged seedling composition in drought (D) and non-drought (N) treatments 1993-1996, within 4 plant functional groups: forbs (FORB), cool-season annual grasses (CSAG), warm-season perennial grasses (WSPG), and cool-season perennial grasses (CSPG). Within a year, drought treatment totals with asterisks differ $(P<0.05$, LSD). Within a plant type and a year, drought treatments with the same upper-case letter do not differ (P > 0.05, L.S.D.). 
ment for continued root growth of drought treatments until late into the 1994 growing season (Heitschmidt et al. 1999). Phenotypic plasticity of roots can allow plants to shift their root biomass to more favorable microsites (Mordenchai et al. 1997, Rethman et al. 1997). In the Bw horizon, root counts in the 2 drought treatments were similar prior to the imposed drought, but differed during drought. Compensatory root growth in soil layers which offer more favorable environments for roots is well documented (Hamblin 1985, Voorhees 1989, Huck and Hoogenboom 1990, Zobel 1991, Jesko et al. 1997). For example, compensatory root growth can occur at deeper soil depths when surface soils have dried (Schuster 1964, Fernandez and Caldwell 1975, Allmaras and Logsdon 1990). Thus Bw horizon roots may reflect drought treatment even though drought influence is not apparent in the A horizon roots.

Grazing treatment effects on root counts appear only in roots in the A horizon on 4 sampling dates. The general trend of fewer shallow roots in grazed plots than ungrazed plots over the entire time of the study, may be the consequence of greater allocation to above-ground growth, removal of annual plant roots by animals, and/or a compensatory shift in root distributions. Shallow roots did not decline immediately after grazing (1994), yet roots in grazed plots did not appear to over-winter well (April 1995). With return of growing season conditions early in 1995, ungrazed plants may have had greater winter root survival than grazed plants. Other explanations for decreased shallow roots with grazing are greater allocation to above-ground production (tillering) of perennials without subsequent root production (Briske and Richards 1995, Heitschmidt et al. 1999) or compensatory shift to deeper roots. Trends in rooting patterns may have been more apparent had we been able to identify roots to species.

\section{Seedbank dynamics}

Grassland seedbanks seldom have a large perennial grass component (Rice 1989, Simpson et al. 1989, Kinucan and Smeins 1992); our results were similar. Combined evidence from production records (Heitschmidt et al. 1999) and our seed bank data indicates that summer defoliation may enhance forb presence when sufficient water is available. Decline in forb seedlings with drought could indicate reduced seed production, induced seed dormancy, or lack of seed viability.
Emerged seedlings of cool-season annual grasses (in this study primarily Japanese brome and sixweeks fescue) were affected little by grazing, but were reduced during and increased following drought treatment. Increases after drought may reflect induction of secondary dormancy in coolseason annual grasses in fall 1994 due to combined imbibition and temperature effects (Baskin and Baskin 1981, Haferkamp et al. 1994, 1995) and subsequent accumulation of seed in 1995 . Similar seedling numbers were found in drought and non-drought plots in 1993. The imposed drought in 1994 clearly reduced germinable seed that year. Drought plots were denied rainfall until mid October and seed was collected on 23 September in 1994. Consequently, many of the seeds produced in 1994 on drought plots may not have had an opportunity to develop completely or germinate before sample collection. We did not measure and must assume seed production in 1995 was similar on drought and non-drought plots. In 1995 however, seedlings were greater on drought than on non-drought plots. A 6-day rainy period in midSeptember 1994, was probably sufficient to allow some seeds to germinate on nondrought plots. Since August and September 1995 rainfall was not conducive to germination of annual brome seeds, drought plots retained the accumulated seeds from the prior fall. Consequently, we documented nearly twice as many germinable annual coolseason grass seeds in late September 1995 than non-drought plots. In the following year, September rains (> $25 \mathrm{~mm}$ ) should have allowed germination of annual brome seeds and reduced seed banks on both drought and non-drought plots. Simultaneous study to document seed production and germination events versus accumulation of seed banks would have greatly enhanced our potential to evaluate secondary dormancy.

Successful establishment of perennial grass seedlings is unlikely and is much more common for annual grasses (Kinucan and Smeins 1992, Major and Pyott 1966, Rice 1989). Cool-season annual grasses could maintain their prevalence during subsequent recovery after drought. Consequently, one might speculate that overall trends in the seedbank the year after drought (decreased shallow roots with grazing, and decreased germinable forb seed with drought), suggest a potential transition favoring cool-season annual grasses. Other work suggests that combined clipping and presence of Japanese brome can decrease standing crop of perennial cool-season grasses (Haferkamp et al. 1998). However, given the flexible composition of seed banks (Thompson and Grime 1979), dominance shifts between forbs, cool season annual grasses, and perennial grasses may be short-lived and greatly influenced by abiotic factors. Our results relative to drought effects probably would have been much different without early spring precipitation in 1994. Community dominance shifts in species composition are unlikely with normal seasonal precipitation patterns, but may occur during years containing this particular sequence of climatic conditions.

\section{Literature Cited}

Albertson, F. W. and J. F. Weaver. 1944. Effects of drought, dust and intensity of grazing on cover and yield of short-grass pastures. Ecol. Mono. 14:1-29.

Albertson, F. W. and J. F. Weaver. 1946. Reduction of ungrazed mixed prairie to short grass as a result of drought and dust. Ecol. Mono. 16:449-463.

Allmaras, R. R. and S. D. Logsdon. 1990. Soil structural influences on the root zone and rhizosphere. p. 8-54. In: Box, J. E. and L. C. Hammond. Rhizosphere Dynamics. AAAS Symposium Series. Westview Press. Boulder, Colo.

Ansley, R. J., P. W. Jacoby, C. H. Meadors, and B. K. Lawrence. 1992. Soil and leaf water relations of differentially moisturestressed honey mesquite (Prosopis glandulosa Torr). J. Arid Environ. 22:147-159.

Bartos, D. L. and D. A. Jameson 1974. A dynamic root model. Amer. Midl. Nat. 91:499-504.

Bartos D. L. and P. L Sims. 1974. Root dynamics of a shortgrass ecosystem J. Range Manage. 27:33-36.

Baskin, J. M. and C. C. Baskin. 1981. Ecology of germination and flowering in the weedy winter annual grass Bromus japonicus. J. Range Manage. 34:369-372.

Briske, D. D. and J. H. Richards. 1995. Plant responses to defoliation : a physiologic, morphologic and demographic evaluation, p. 635-710. In: D. J. Bedunah and R. E. Sosebee (eds.). Wildland Plants: Physiological Ecology and Developmental Morphology. Soc. for Range Manage. Denver, Colo.

Carmer, S. G. and M. R. Swanson. 1971. Detection of differences between means: A Monte Carlo study of five pairwise multiple comparison procedures. Agron. J. 63:940-945.

Carter, J. F. and A. G. Law. 1948. The effect of clipping upon the vegetative development of some perennial grasses. 1948. J. Amer. Soc. Agron 40:1084-1091.

Cook, C. W. and J. Stubbendieck. 1986. Range research: basic problems and techniques. Soc. for Range Manage. Denver, Colo. 
Crider, F. J. 1955. Root-growth stoppage resulting from defoliation of grass. USDASCS Tech. Bull. 1102.

Dorn, R. D. 1984. Vascular plants of Montana. Mountain West Pub. Cheyenne, Wyo.

Eneboe, E. J. 1996. Tiller dynamics of blue grama and western wheatgrass subjected to drought and grazing. MS Thesis. Montana State Univ. Bozeman, Mont.

Fernandez, O. A. and M. M. Caldwell. 1975. Phenology and dynamics of root growth of three cool semi-desert shrubs under field conditions. J. Ecol. 63:703-714.

Haferkamp, M. R., M. D. MacNeil, and M. G. Karl. 1995. Induction of secondary dormancy in Japanese brome (Bromus japonicus), p.199-200 In: N. West (ed.). Proc. $5^{\text {th }}$ Int. Rangeland Congress. 1995. Salt Lake City, Utah. Soc. Range Manage. Denver, Colo.

Haferkamp, M. R., M. G. Karl, and M. D. MacNeil. 1994. Influence of storage, temperature, and light on germination of Japanese brome seed. J. Range Manage. 47:140-144.

Haferkamp, M. R., R. K. Heitschmidt, and M. G. Karl. 1998. Clipping and Japanese brome reduce western wheatgrass standing crop. J. Range Manage. 51:692-698.

Hamblin, A. P. 1985. The influence of soil structure on water movement, crop root growth, and water uptake. Adv. in Agron. 38:95-158

Harper, J. L. 1977. Population biology of plants. Academic Press. San Diego, Calif.

Heitschmidt, R. K., M. R. Haferkamp, M. G. Karl, and A. L. Hild. 1999. Drought and grazing: I Effects on quantity of forage produced. J. Range Manage. 52:440-446.

Huck, M. G. and Gerrit Hoogenboom. 1990. Soil and plant root water flux in the rhizosphere. p. 268-312. In: Box, J. E. and L. C. Hammond (eds.). Rhizosphere Dynamics. AAAS Symposium Series. Westview Press. Boulder, Colo.

Jesko, T., J. Navara, and K. Dekankova. 1997. Root growth and water uptake by flowering maize plants, under drought conditions p. 270-271 In: A. Altman and Y. Waisel (eds.). Biology of Root Formation. Proc. $2^{\text {nd }}$ International Symposium on Biology of Root Formation and Development. 23-28 June 1996. Jerusalem, Israel. Plenum Press. New York, N. Y.

Kinucan, R. J. and F. E. Smeins. 1992. Soil seed bank of a semiarid Texas grassland under three long-term (36 years) grazing regimes. Amer. Midl. Nat. 128:11-21.

Kuchler, A. W. 1964. Potential natural vegetation of the coterminous United States. Amer. Geogr. Soc. Spec. Pub. 36. New York, N. Y.

Larsen, W., R.K. Heitschmidt, and $B$. Knapp. 1993. Rainout shelter design. Paper No. PNW 93-105. Amer. Soc. Agr. Eng., Lethbridge, Alb. Sept. 1993.

Major, J. and W. T. Pyott. 1966. Buried, viable seeds in two California bunchgrass sites and their bearing on the definition of a flora. Vegetatio. 13:253-282.
McNaughton, S. J., F. F. Banyikwa, and M. M. McNaughton. 1998. Root biomass and productivity in a grazing ecosystem: the Serengeti. Ecol. 79(2):587-592.

Mordenchai, G., Z. Abramsky and O. Falik. 1997. Density dependent habitat selection in plants, p. 271-274. In: A. Altman and Y. Waisel (eds.), Biology of root formation and development. Proc. Second Int. Symp. June 23-28. Jerusalem, Israel. Plenum.

National Oceanic and Atmospheric Administration. 1996. Climatological data, Montana annual summary. Nat. Climatol. Data Center, Asheville, N. C.

Rethman, N., P. S. Venter and J. P. Lindeque. 1997. Influence of water stress on the mass of roots of buffelgrass selections and on their distribution, p.249-252. In: A. Altman and Y. Waisel (eds.), Biology of root formation and development. Proc. Second Int. Symp. June 23-28. Jerusalem, Israel. Plenum.

Rice, K. J. 1989. Impacts of seed banks on grassland community structure and population dynamics, p. 211-230. In: Leck, M., V. T. Parker and R. L. Simpson, (eds.) Ecology of soil seedbanks. Academic Press, Inc. San Diego, Calif.

Richards, J. H. 1984. Root growth response to defoliation in two Agropyron bunchgrasses: field observations with an improved root periscope. Oecologia 64:21-25.

Robertson, J. H. 1933. Effect of frequent clipping on the development of certain grass seedlings. Plant Phys. 8:425-447.

Schuster, J. L. 1964. Root development of native plants under three grazing intensities. Ecol. 45:63-70.

Shapiro, S. S. and M. B. Wilk. 1965. An analysis of variance test for normality (complete samples). Biometrika. 52:591-611.

Simpson, R. L., M. A. Leck, and V. T. Parker. 1989. Seed banks: general concepts and methodological issues. p. 3-8. In: Leck, M. A., V. T. Parker, and R. L. Simpson. Ecology of soil seed banks. Academic Press. San Diego, Calif.

Taylor, H. M. ed. 1987. Minirhizotron observation tubes: Methods and applications for measuring rhizosphere dynamics. Amer. Soc. Agron. Spec. Pub. No. 50. Madison Wis.

Thompson, K. and J. P. Grime. 1979. Seasonal variation in the seed banks of herbaceous species in ten contrasting habitats. J. Ecol. 67:893-921.

Upchurch, D. R. 1987. Conversion of minirhizotron-root intersections to root length density, p.51-65 In: Taylor, H. M. (ed.) Minirhizotron observation tubes: Methods and applications for measuring rhizosphere dynamics. Amer. Soc. Agron. Spec. Pub. No. 50. Madison, Wis.

USDA-NRCS. 1996. Custer County Area Soil Survey Maps, Fort Keogh, unpublished data. Miles City, Mont.
Voorhees, W. B. 1989. Root activity related to shallow and deep compaction. p. 173-186. In: W. E. Larsen (ed.). Mechanics and Related Processes in Structured Agricultural Soils. Kluwer Academic Press, Dordrecht.

Waddington, J. 1971. Observation of plant roots in situ. Can. J. Bot. 49:1850-1852.

Zobel, R. W. 1991. Root growth and development, p.61-71. In: D. Keister and P. Cregan (eds.), Symp. Proc. on Rhizosphere and plant growth. 8-11 May 1989. Beltsville Agr. Res. Center (BARC), Beltsville, Md. Kluwer. 